\section{Dry Matter Content and Stability of Carotenoids in Kale and Spinach During Drying}

\author{
Mark Lefsrud ${ }^{1,5}$ \\ Bioresource Engineering, McGill University, 21111 Lakeshore Boulevard, \\ Ste-Anne-de-Bellevue, Quebec, H9X 3V9, Canada
}

Dean Kopsell ${ }^{1}$ and Carl Sams ${ }^{2}$
Plant Sciences, The University of Tennessee, Knoxville, TN 37996

Jim Wills ${ }^{3}$

Biosystems Engineering and Soil Science, The University of Tennessee, Knoxville, TN 37996

\author{
A.J. Both ${ }^{4}$ \\ Plant Biology and Pathology, Rutgers, New Brunswick, NJ 08901
}

Additional index words. $\beta$-carotene, Brassica, crop production, dry matter, functional foods, lutein, Spinacia

\begin{abstract}
Drying of spinach (Spinacia oleracea L.) and kale (Brassica oleracea L. var. acephala D.C.) is required to determine percentage of dry matter (\%DM) and pigment concentration of fresh leaves. 'Melody' spinach and 'Winterbor' kale were greenhousegrown in hydroponic nutrient solutions containing 13 or $105 \mathrm{mg} \cdot \mathrm{L}^{-1} \mathrm{~N}$. Using vacuum freeze dryers and convection ovens, plant tissues were dried for $120 \mathrm{~h}$ at five different temperature treatments: 1) freeze drying at $-25^{\circ} \mathrm{C} ; 2$ ) freeze drying at $0{ }^{\circ} \mathrm{C} ; 3$ ) vacuum drying at $\left.+25{ }^{\circ} \mathrm{C} ; 4\right)$ oven drying at $+50{ }^{\circ} \mathrm{C}$; and 5) oven drying at $+75^{\circ} \mathrm{C}$. Spinach leaf tissue \%DM was affected, but kale \%DM was unaffected by drying temperature. Spinach and kale leaf tissue \%DM were both affected by $\mathrm{N}$ level. The high $\mathrm{N}$ spinach decreased from 7.3 to $6.4 \% \mathrm{DM}$ when drying temperature increased from +25 to $+75^{\circ} \mathrm{C}$. The low $\mathrm{N}$ spinach decreased from 12.7 to $9.6 \% \mathrm{DM}$ as the drying temperature increased from -25 to $+50{ }^{\circ} \mathrm{C}$. Kale averaged from $14.8 \% \mathrm{DM}$ for the high $\mathrm{N}$ treatment and from $\mathbf{2 1 . 8 \% D M}$ for the low $\mathrm{N}$ treatment. However, drying temperature did not have a significant impact on measured \%DM in kale. Lutein, $\beta$-carotene, and chlorophyll levels for both spinach and kale leaf tissue were affected by drying temperature. Measured concentrations of all pigments decreased over $70 \%$ as the drying temperature increased from -25 to $75^{\circ} \mathrm{C}$. The largest pigment fresh and dry weight concentrations for spinach and kale were measured at drying temperatures below $+25^{\circ} \mathrm{C}$. The spinach and kale samples dried between -25 and $+25^{\circ} \mathrm{C}$ were not significantly different from each other in $\% \mathrm{DM}$ or pigment concentration measured on a dry or fresh weight basis. Thus, drying leaf tissue for accurate pigment analysis requires temperatures below $+25^{\circ} \mathrm{C}$ using vacuum or freeze drying technology.
\end{abstract}

Determination of carotenoid concentrations in plant tissue requires dried samples for analysis (Kopsell et al., 2004; Tai and Chen, 2000). However, the plant growth environment can have a significant impact on the water content of the harvested plant (Lefsrud

Received for publication 26 Feb. 2008. Accepted for publication 19 May 2008 .

This paper was funded in part by a grant received by the Cooperative State Research, Education, and Extension Service, U.S. Department of Agriculture, under Agreement No. 2001-52102-11254.

We thank Dr. Joanne Curran-Celentano and Pam Bishop for their help during this project.

${ }^{1}$ Assistant Professor.

${ }^{2}$ Professor.

${ }^{3}$ Professor and Extension Specialist.

${ }^{4}$ Associate Extension Specialist.

${ }^{5}$ To whom reprint requests should be addressed; e-mail mark.lefsrud@mcgill.ca et al., 2005, 2006). A number of methods are used to remove tissue moisture before analysis, including convection oven drying, freeze drying, vacuum drying, air drying, and microwave drying (Diaz-Maroto et al., 2004; Ingram et al., 2000; Karathanos, 1999; Litvin et al., 1998; Stegen et al., 1998).

To determine the effect of drying temperature on plant samples, Stegen et al. (1998) compared the water content of a number of plants using microwave, oven, and vacuum drying (performed at $22^{\circ} \mathrm{C}$ ). Alfalfa (Medicago sativa L.), onion (Allium cepa L.), corn (Zea mays L.), and potato (Solanum tuberosum L.) had a final moisture content that was not significantly different among the three drying methods, but bean (Pinguicula vulgaris L.), bean shell, and garlic (Allium sativum L.) were significantly different. The microwave oven and vacuum drying of the latter three plant samples did not significantly affect the moisture measurement, but oven drying resulted in a significant change in the measured moisture content.

Moisture content within biological samples changes during drying and can result in the release of organic compounds, volatile organic compounds (VOCs), destruction of pigments, and changes in chemical composition. The loss of VOC through drying of a wide variety of plants has been reported (Diaz-Maroto et al., 2002a, 2002b, 2004; Ingram et al., 2000). However, the published literature on release of organic compounds not listed as VOC is limited. At temperatures greater than $65^{\circ} \mathrm{C}$, Karathanos (1999) reported that decomposition of low-molecularweight sugars (specifically fructose), in addition to the evaporation of water, could occur within the sample. An ASABE standard (ASABE, 2007) recommends that for further analytical analysis of plant forages, drying temperatures less than $65^{\circ} \mathrm{C}$ should be used. Diaz-Maroto et al. (2002a) found that oven drying and air drying bay leaf (Laurus nobilis L.) did not affect the aroma of the fresh herb; however, freeze drying resulted in a reduction. Diaz-Maroto et al. (2002b) reported that oven drying and freeze drying of parsley (Petroselinum crispum L.) resulted in a decrease in VOC within the sample, but air drying resulted in few losses. Oven-dried and freeze-dried basil (Ocimum basilicum L.) had a decrease in VOC, but air-dried basil was not different compared with a fresh sample (Diaz-Maroto et al., 2004).

Carotenoids and other plant compounds can also be affected by drying temperature. A significant decrease in lutein and $\beta$-carotene was measured in daylily (Hemerocallis disticha Donn ex Sweet) when oven dried at $48^{\circ} \mathrm{C}$ compared with $-53^{\circ} \mathrm{C}$ freeze drying (Tai and Chen, 2000). Cinar (2004) reported that freeze drying reduced the losses of carotenoids during storage in orange peel [Citrus sinensis (L.) Osbeck], potato, and carrot (Daucus carota L.). Alomar et al. (1999) reported that oven drying of silage resulted in a reduction in crude protein and an increase in crude fiber, neutral detergent fiber, and acid detergent fiber when compared with freeze drying.

Carotenoids are lipid-soluble, yellow, orange, and red pigments produced by plants, algae, and bacteria. In higher plants, carotenoids function in photoprotection as lightharvesting antennae pigments and free radical scavengers (Miki, 1991; Taiz and Zeiger, 1998; Tracewell et al., 2001). Two important dietary carotenoids in human health maintenance are lutein and $\beta$-carotene. Increased intake of lutein and $\beta$-carotene has been associated with reduced risk of lung cancer and chronic eye diseases such as cataracts and age-related macular degeneration (Ames et al., 1995; Landrum and Bone, 2001; Le Marchand et al., 1993; Semba and Dagnelie, 2003). Increasing the lutein and $\beta$-carotene concentrations in vegetable crops through cultural management techniques would be beneficial to the health status of consumers.

Kale (Brassica oleracea L. var. acephala D.C.) ranks highest and spinach (Spinacia 
oleracea L.) ranks second among vegetable crops for lutein and $\beta$-carotene content (Holden et al., 1999; U.S. Dept. Agr., 2002). However, kale has low consumption rates with per capita fresh intake of less than $0.33 \mathrm{~kg} /$ year in the United States (Lucier and Plummer, 2003). Spinach has one of the highest consumption rates among green, leafy vegetables in the United States with per capita intakes of $0.73,0.09$, and $0.36 \mathrm{~kg} /$ year for fresh, canned, and frozen markets, respectively (Lucier and Plummer, 2003). With increased interest in dried plant material for human health within supplement markets, the purpose of this study was to determine the effect of drying conditions on water content, measured dry matter content, and stability of pigments (carotenoids and chlorophylls) in kale and spinach.

\section{Material and Methods}

\section{Plant culture}

'Melody' spinach and 'Winterbor' kale (Johnny's Selected Seed, Winslow, ME) were seeded on 22 Feb. 2005 into rockwool growing cubes (Grodan A/S, Dk-2640, Hedehusene, Denmark). The seeds were germinated and grown in a greenhouse $\left(22^{\circ} \mathrm{C}\right.$ day/ $14{ }^{\circ} \mathrm{C}$ night) under natural lighting conditions (Knoxville, TN, lat. $35^{\circ} 57^{\prime \prime} \mathrm{N}$ ). Plants were grown according to the method described in Lefsrud et al. (2007). Peter's 20N-6.9P16.6K water-soluble fertilizer (Scotts, Marysville, $\mathrm{OH}$ ) was applied every $5 \mathrm{~d}$ at a rate of $200 \mathrm{mg} \cdot \mathrm{L}^{-1}$. After 3 weeks, the plants were transferred to containers (Rubbermaid Inc., Wooster, $\mathrm{OH}$ ) holding $9 \mathrm{~L}$ of nutrient solution (Hoagland and Arnon, 1950) on three independent benches. Six plants were transferred into $2-\mathrm{cm}$ round holes arranged in a $10.6 \times 9.5-\mathrm{cm}$ spacing in each container lid. Plants were grown under two nitrogen $(\mathrm{N})$ treatment levels of 13 and $105 \mathrm{mg} \cdot \mathrm{L}^{-1}$. The ratio of $\mathrm{NO}_{3}-\mathrm{N}$ to $\mathrm{NH}_{4}-\mathrm{N}$ was kept constant at 3:1 and solutions were changed every 2 weeks. The experimental design was a randomized complete block (benches) with three replications of the two-way factorial $(\mathrm{N}$ treatment and plant species).

\section{Biomass determination}

Plants were harvested after 4 weeks in the hydroponic system on 12 Apr. 2005. At harvest, shoot and root tissues were separated and weighed. Shoot tissues were washed with soap (Aquet; Bel-art Products, Pequannock, NJ), rinsed, and blotted dry with paper towels. The third through sixth true leaves were removed from each plant, combined from each $\mathrm{N}$ treatment, randomly separated into $\approx 5$-g samples, weighed, and assigned one of the drying treatments. These samples were stored at $-80{ }^{\circ} \mathrm{C}$ before drying. The five drying treatments $(\mathrm{T})$ were: 1$)$ freeze drying at $-25^{\circ} \mathrm{C} ; 2$ ) freeze drying at $0{ }^{\circ} \mathrm{C} ; 3$ ) vacuum drying at $+25{ }^{\circ} \mathrm{C}$; 4) oven drying at $+50{ }^{\circ} \mathrm{C}$; and 5) oven drying at $+75{ }^{\circ} \mathrm{C}$. The freeze dryer was a LabConCo (Kansas City, MO) Freezezone 6 with the vacuum at 0.006 mbar, the condenser at $-40{ }^{\circ} \mathrm{C}$, and the stoppering tray dryer containing the samples set at the treatment temperature. The convection oven was a Fisher (Hampton, $\mathrm{NH}$ ) Isotemp oven 300 series, model 338F. Drying treatments were replicated three times per species and per $\mathrm{N}$ treatment. For each treatment, the shoot material was dried for $100 \mathrm{~h}$, weighed, and dried for another $20 \mathrm{~h}$ to confirm equilibrium moisture content. Samples were stored at $-80^{\circ} \mathrm{C}$ before further analysis.

\section{Carotenoid and chlorophyll determination}

Tissue extraction. The dried tissues samples were ground with dry ice in a kitchen grinder (Handy Chopper Plus, HC 3000; Household Products, Shelton, CT). Pigments were extracted and separated according to Kopsell et al. (2004). A 0.1-g subsample was placed into a Potter-Elvehjem tissue grinder tube (Kontes, Vineland, NJ) and hydrated with $0.8 \mathrm{~mL}$ of deionized water. The sample was placed in a water bath at $40{ }^{\circ} \mathrm{C}$ for 20 min. After hydration, $0.8 \mathrm{~mL}$ of the internal standard, ethyl- $\beta$-apo- 8 ' -carotenoate (Sigma Chemical Co., St. Louis) and $2.5 \mathrm{~mL}$ of tetrahydrofuran (THF) stabilized with 25 $\mathrm{mg} \cdot \mathrm{L}^{-1} \quad$ 2,6-Di-tert-butyl-4-methoxyphenol were added. The sample was homogenized in the tube with 25 insertions of the grinder pestle attached to a drill press (Model Craftsman 15 inch Drill Press; Sears Co., Hoffman Estates, IL) at $540 \mathrm{rpm}$ while immersed in ice. The tube was placed into a clinical centrifuge for $3 \mathrm{~min}$ at $500 \mathrm{~g}_{\mathrm{n}}$. The supernatant was removed with a Pasteur pipet, placed into a conical $15-\mathrm{mL}$ test tube, capped, and held on ice. The sediment was resuspended in $2 \mathrm{~mL}$ THF and homogenized and centrifuged again. The supernatant was collected and combined with the first extracted supernatant. The extraction procedure was repeated twice more until the supernatant was colorless. The sediment was discarded and the combined four supernatants were reduced to $0.5 \mathrm{~mL}$ using N gas (Model N-EVAP 111; Organomation, Berlin, ME). A total of $2.5 \mathrm{~mL}$ of $\mathrm{MeOH}$ and $2 \mathrm{~mL}$ of THF were added to the $0.5-\mathrm{mL}$ sample, vortexed, and filtered through a $0.2-\mu \mathrm{m}$ polytetrafluoroethylene (PTFE) filter (Model Econofilter PTFE 25/20; Agilent Technologies, Palo Alto, CA) using a 5-mL syringe (Becton, Dickinson and Company, Franklin Lakes, NJ) before high-performance liquid chromatography (HPLC) analysis.

High-performance liquid chromatography analysis. A HPLC unit with photodiode array detector (Agilent 1100; Agilent Technologies, Palo Alto, CA) was used for pigment separation. Chromatographic separations were achieved using a $250 \times 4.6 \mathrm{~mm}$ i.d., $5-\mu \mathrm{m}$ analytical scale polymeric $\mathrm{C}_{30}$ reverse-phase column (ProntoSIL; MAC-MOD Analytical, Chadds Ford, PA), which allowed for effective separation of chemically similar carotenoid compounds. The column was equipped with a $10 \times 4.0 \mathrm{~mm}$ i.d. guard cartridge and holder (ProntoSIL) and was maintained at $30{ }^{\circ} \mathrm{C}$ using a thermostatted column compartment. All separations were achieved isocratically using a binary mobile phase of $11 \%$ methyl tert-butyl ethanol, $88.9 \% \mathrm{MeOH}$, and $0.1 \%$ triethylamine $(\mathrm{v} / \mathrm{v})$. The flow rate was $1.0 \mathrm{~mL} \cdot \mathrm{min}$ with a run time of $55 \mathrm{~min}$ followed by a 5 -min equilibration before the next injection. Eluted compounds from a $10-\mu \mathrm{L}$ injection were detected at 453 (carotenoids and internal standard), 652 [chlorophyll $a(\mathrm{Chl} a)$ ], and 665 [chlorophyll $b(\mathrm{Chl}$ b)] $\mathrm{nm}$ and data were collected, recorded, and integrated using ChemStation Software (Agilent Technologies). Internal standard recovery ranged from $62 \%$ to $100 \%$ with a mean for all samples at $80 \%$. Peak assignment for individual pigments was performed by comparing retention times and line spectra obtained from photodiode array detection using external standards of lutein (Carotenature, Lupsingen, Switzerland), $\beta$-carotene, Chl $a$, and Chl $b$ (Sigma Chemical Co.). The concentration of the external pigment standards were determined spectrophotometrically using methods described by Davies and Köst (1988). Slurried Spinach 2385 standard reference material (National Institute of Science and Technology, Gaithersburg, MD) was used for method validation.

\section{Statistical analysis}

Data sets were analyzed by a split plot, GLM procedure using SPSS (Chicago). Analysis of variance was used to determine the significance of the main effects of $\mathrm{N}$ treatments and drying temperature and of their interactions. The relationship between experimental dependent variables and $\mathrm{N}$ treatments was determined by regression analysis using SPSS (Steel and Torrie, 1980).

\section{Results}

The moisture content of the tissue samples did not change significantly between the first $100 \mathrm{~h}$ of drying when compared with the final $20 \mathrm{~h}$. Equilibrium moisture content was confirmed for all drying methods using this two-step drying process.

Spinach biomass accumulation. The measured percent dry matter $(\% \mathrm{DM})$ for spinach was influenced by $\mathrm{N}$ treatment level $(P \leq$ $0.01)$. The measured $\% \mathrm{DM}$ for spinach was influenced by drying temperature $(P=$ 0.011 ). No significant variation was accounted for by the interaction between $\mathrm{N}$ treatment level and drying temperature $(P=$ $0.081)$. Average $\% \mathrm{DM}$ for the spinach increased from $7.0 \%$ for the high $\mathrm{N}$ treatment to $10.7 \%$ for the low $\mathrm{N}$ treatment (Table 1 ; Fig. 1). The average \%DM for the high $\mathrm{N}$ spinach treatment varied among the drying temperature treatments and resulted in an increase from $6.4 \%$ for the $+75{ }^{\circ} \mathrm{C}$ convection oven to $7.3 \%$ for the $+25{ }^{\circ} \mathrm{C}$ vacuum dryer. The average \%DM for the low $\mathrm{N}$ spinach treatment increased from $9.6 \%$ for the $+50{ }^{\circ} \mathrm{C}$ convection oven to $12.7 \%$ for the $-25{ }^{\circ} \mathrm{C}$ freeze dryer. Spinach leaf tissue $\% \mathrm{DM}$ decreased linearly with increases in drying temperature for both the high $\mathrm{N}$ $\left[\% \mathrm{DM}=7.2\right.$ to $0.008(\mathrm{~T}), r^{2}=0.27, P=$ $0.05]$ and low $\mathrm{N}$ treatments $[\% \mathrm{DM}=11.4$ to $\left.0.02(\mathrm{~T}), r^{2}=0.49, P=0.004\right]$. 
Table 1. Mean pigment concentrations ${ }^{2}$ expressed on a fresh weight (FM) basis in the leaf tissues of 'Melody' spinach grown with two nitrogen levels and five drying temperatures.

\begin{tabular}{|c|c|c|c|c|c|}
\hline \multirow{2}{*}{$\begin{array}{l}\text { Drying } \\
\text { temperature }\left({ }^{\circ} \mathrm{C}\right)\end{array}$} & \multirow[b]{2}{*}{$\% \mathrm{DM}$} & \multicolumn{4}{|c|}{ Pigment concn $\left(\mathrm{mg} / 100 \mathrm{~g}^{-1} \mathrm{FM}\right)$} \\
\hline & & Lutein & $\beta$-carotene & Chl $a^{\mathrm{y}}$ & Chl $b^{y}$ \\
\hline & \multicolumn{5}{|c|}{ Spinach high nitrogen $\left(105 \mathrm{mg} \cdot \mathrm{L}^{-1}\right)$} \\
\hline+75 & $6.4 \pm 0.1$ & $2.2 \pm 0.1$ & $1.1 \pm 0.1$ & $0.8 \pm 0.3$ & $0.4 \pm 0.1$ \\
\hline+50 & $6.9 \pm 0.2$ & $5.1 \pm 0.5$ & $2.1 \pm 0.2$ & $9.5 \pm 2.3$ & $5.7 \pm 1.3$ \\
\hline+25 & $7.3 \pm 0.1$ & $8.0 \pm 0.5$ & $4.0 \pm 0.3$ & $79.2 \pm 4.6$ & $29.2 \pm 1.6$ \\
\hline 0 & $7.2 \pm 0.1$ & $8.8 \pm 0.6$ & $4.5 \pm 0.2$ & $86.0 \pm 5.6$ & $31.8 \pm 1.3$ \\
\hline-25 & $7.2 \pm 0.2$ & $9.0 \pm 0.1$ & $4.9 \pm 0.1$ & $91.6 \pm 3.1$ & $31.9 \pm 0.8$ \\
\hline \multicolumn{6}{|l|}{ Contrasts } \\
\hline Linear & ** & $* * *$ & $* * *$ & $* * *$ & $* * *$ \\
\hline \multirow[t]{2}{*}{ Quadratic } & $* *$ & $* * *$ & *** & $* * *$ & *** \\
\hline & \multicolumn{5}{|c|}{ Spinach low nitrogen $\left(13 \mathrm{mg} \cdot \mathrm{L}^{-1}\right)$} \\
\hline+75 & $10.5 \pm 0.5$ & $2.2 \pm 0.4$ & $1.3 \pm 0.2$ & $3.1 \pm 1.7$ & $1.5 \pm 0.2$ \\
\hline+50 & $9.6 \pm 0.7$ & $3.8 \pm 0.2$ & $1.2 \pm 0.1$ & $1.6 \pm 0.6$ & $2.2 \pm 0.1$ \\
\hline+25 & $11.4 \pm 0.7$ & $8.2 \pm 0.6$ & $3.2 \pm 0.3$ & $59.1 \pm 6.2$ & $22.3 \pm 0.3$ \\
\hline 0 & $10.3 \pm 0.1$ & $7.0 \pm 0.4$ & $2.7 \pm 0.2$ & $51.5 \pm 2.8$ & $18.8 \pm 0.3$ \\
\hline-25 & $12.7 \pm 0.9$ & $9.8 \pm 1.4$ & $4.2 \pm 0.7$ & $75.8 \pm 9.9$ & $28.3 \pm 0.4$ \\
\hline \multicolumn{6}{|l|}{ Contrasts } \\
\hline Linear & * & $* * *$ & *** & $* * *$ & $* * *$ \\
\hline Quadratic & NS & $* * *$ & $* * *$ & $* * *$ & $* * *$ \\
\hline
\end{tabular}

${ }^{\mathrm{z}}$ Mean composition of leaf tissue (pooled six-plant subsample) of three replications $\pm \mathrm{SE}$.

${ }^{\mathrm{y}} \mathrm{Chl} a=$ chlorophyll $a$; $\mathrm{Chl} b=$ chlorophyll $b$.

Ns, ****,****Nonsignificant or significant at $P \leq 0.05,0.01,0.001$, respectively.

$\% \mathrm{DM}=$ percentage of dry matter.

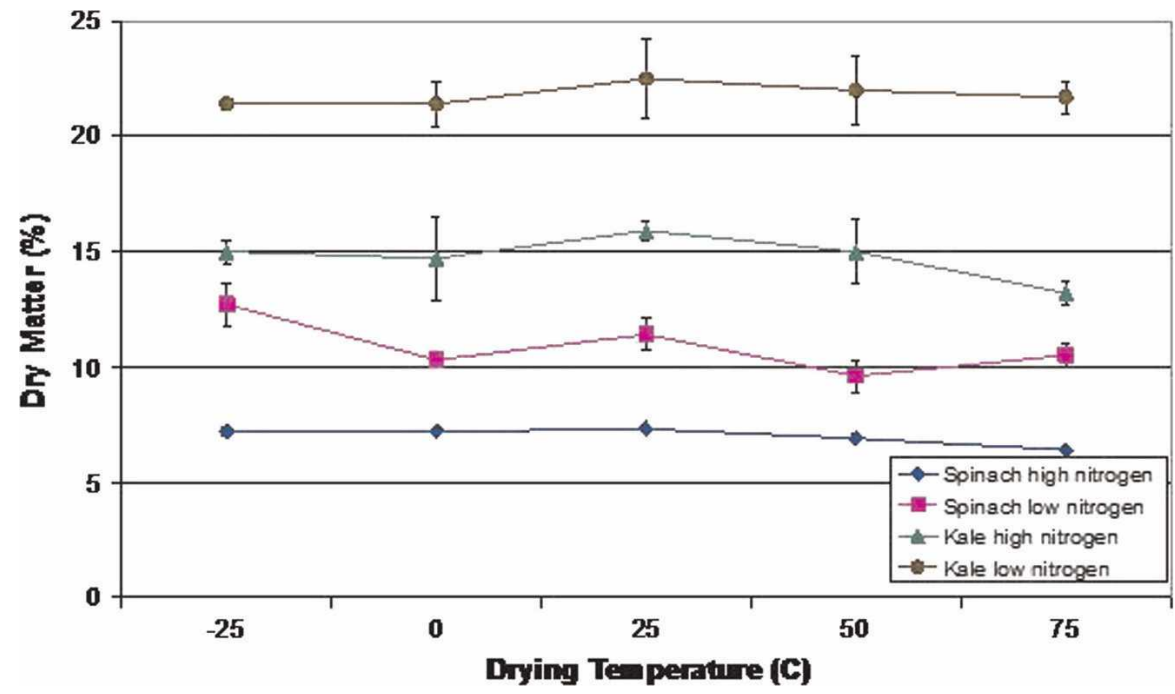

Fig. 1. Effect of drying temperature on dry matter of shoot tissue in kale and spinach grown under high (105 $\left.\mathrm{mg} \cdot \mathrm{L}^{-1}\right)$ and low $\left(13 \mathrm{mg} \cdot \mathrm{L}^{-1}\right)$ nitrogen levels. Five drying temperatures: $-25^{\circ} \mathrm{C}$ freeze drying, $0{ }^{\circ} \mathrm{C}$ freeze drying, $+25^{\circ} \mathrm{C}$ vacuum drying, $+50{ }^{\circ} \mathrm{C}$ convection oven, and $+75{ }^{\circ} \mathrm{C}$ convection oven.

Spinach carotenoid and chlorophyll pigment accumulation. Maximum spinach tissue lutein accumulation expressed on a fresh weight (FM) basis was $9.8 \mathrm{mg} / 100 \mathrm{~g}^{-1}$ for the low $\mathrm{N}$ treatment at the $-25^{\circ} \mathrm{C}$ drying temperature (Table 1). Spinach leaf tissue lutein concentrations responded to drying temperature $(P \leq 0.001)$ but not to $\mathrm{N}$ treatment $(P=0.273)$ nor their interaction $(P=$ $0.203)$. Spinach leaf tissue lutein decreased linearly with increases in drying temperature for both the high $\mathrm{N}$ [lutein $\mathrm{FM}=8.4$ to $0.07(\mathrm{~T})$, $\left.r^{2}=0.84, P \leq 0.001\right]$ and low $\mathrm{N}$ level [lutein $\mathrm{FM}=8.1$ to $\left.0.07(\mathrm{~T}), r^{2}=0.76, P \leq 0.001\right]$.

Maximum spinach tissue $\beta$-carotene accumulation expressed on a FM basis was $4.9 \mathrm{mg} / 100 \mathrm{~g}^{-1}$ under the high $\mathrm{N}$ treatment at the $-25{ }^{\circ} \mathrm{C}$ drying temperature (Table 1). Spinach leaf tissue $\beta$-carotene concentrations the high $\mathrm{N}$ [Chl $a \mathrm{FM}=79.3$ to $1.0(\mathrm{~T}), r^{2}=$ $0.83, P \leq 0.001$ ] and low N treatments [Chl $a$ $\mathrm{FM}=57.7$ to $0.8(\mathrm{~T}), r^{2}=0.78, P \leq 0.001$; Table 1]. Spinach leaf tissue Chl $b$ also decreased linearly with increases in drying temperature for both the high $\mathrm{N}[\mathrm{Chl} b \mathrm{FM}=$ 28.7 to $\left.0.4(\mathrm{~T}), r^{2}=0.82, P \leq 0.001\right]$ and low $\mathrm{N}$ treatments [Chl $b \mathrm{FM}=21.6$ to $0.3(\mathrm{~T}), r^{2}=$ $0.77, P \leq 0.001$; Table 1].

Maximum spinach tissue lutein accumulation expressed on a dry weight (DM) basis was $1.3 \mathrm{mg} \cdot \mathrm{g}^{-1}$ for the high $\mathrm{N}$ treatment and the $-25{ }^{\circ} \mathrm{C}$ drying temperature (Table 2). Spinach leaf tissue lutein concentrations responded to drying temperature $(P \leq$ $0.001), \mathrm{N}$ treatment $(P \leq 0.001)$, and to the interaction between $\mathrm{N}$ treatment and drying temperature $(P=0.008)$. Spinach leaf tissue lutein decreased linearly with increases in drying temperature for both the high $\mathrm{N}$ [lutein $\mathrm{DM}=1.16$ to $\left.0.01(\mathrm{~T}), r^{2}=0.84, P \leq 0.001\right]$ and low $\mathrm{N}$ treatment [lutein $\mathrm{DM}=0.70$ to $\left.0.01(\mathrm{~T}), r^{2}=0.78, P \leq 0.001\right]$.

Maximum spinach tissue $\beta$-carotene accumulation expressed on a DM basis was $0.67 \mathrm{mg} \cdot \mathrm{g}^{-1}$ for the high $\mathrm{N}$ treatment and the $25^{\circ} \mathrm{C}$ drying temperature (Table 2). Spinach leaf tissue $\beta$-carotene concentrations responded to drying temperature $(P \leq 0.001)$, $\mathrm{N}$ treatment $(P \leq 0.001)$, and to the interaction between $\mathrm{N}$ treatment and drying temperature $(P \leq 0.001)$. Spinach leaf tissue $\beta$ carotene decreased linearly with increases in drying temperature for both the high $\mathrm{N}[\beta$ carotene $\mathrm{DM}=0.60$ to $0.01(\mathrm{~T}), r^{2}=0.89, P$ $\leq 0.001]$ and low $\mathrm{N}$ treatments $[\beta$-carotene $\mathrm{DM}=0.30$ to $\left.0.001(\mathrm{~T}), r^{2}=0.74, P \leq 0.001\right]$.

Spinach leaf tissue DM Chl $a$ and $b$ concentrations responded to drying temperature $(P \leq 0.001), \mathrm{N}$ treatment $(P \leq 0.001)$, and to the interaction between $\mathrm{N}$ treatment and drying temperature $(P \leq 0.001)$. Spinach leaf tissue Chl $a$ decreased linearly with increases in drying temperature for both the high N [Chl $a=11.0$ to 0.1 (T), $r^{2}=0.83, P \leq$ $0.001]$ and low $\mathrm{N}$ treatments [Chl $a \mathrm{DM}=4.9$ to $0.07(\mathrm{~T}), r^{2}=0.80, P \leq 0.001$; Table 2]. Spinach leaf tissue Chl $b$ decreased linearly with increases in drying temperature for both the high $\mathrm{N}[\mathrm{Chl} b \mathrm{DM}=4.0$ to 0.05 (T), $\left.r^{2}=0.82, P \leq 0.001\right]$ and low $\mathrm{N}$ treatments [Chl $b=1.9$ to 0.07 (T), $r^{2}=0.79, P \leq$ 0.001; Table 2].

Kale biomass accumulation. Percent dry matter for kale was influenced by $\mathrm{N}$ treatment level $(P \leq 0.01)$. No significant influence was measured for the kale drying temperature $(P=0.63)$ or for the interaction between $\mathrm{N}$ treatment and drying temperature $(P=$ $0.90)$. Average $\% \mathrm{DM}$ for the kale increased from $14.8 \%$ for the high $\mathrm{N}$ treatment to $21.8 \%$ for the low $\mathrm{N}$ treatment (Table 3 ). The average $\% \mathrm{DM}$ for the high $\mathrm{N}$ kale treatment increased from $13.2 \%$ for the $+75{ }^{\circ} \mathrm{C}$ convection oven to $15.9 \%$ for the $+25{ }^{\circ} \mathrm{C}$ vacuum dryer. The average $\% \mathrm{DM}$ for the low $\mathrm{N}$ kale treatment increased from $21.4 \%$ for the $-25{ }^{\circ} \mathrm{C}$ freeze dryer to $22.5 \%$ for the $+25{ }^{\circ} \mathrm{C}$ vacuum dryer. No trend was measured for the kale \%DM for either the high or low $\mathrm{N}$ treatment. 
Table 2. Mean pigment concentrations ${ }^{z}$ expressed on a dry weight (DM) basis in the leaf tissues of 'Melody' spinach grown with two nitrogen levels and five drying temperatures.

\begin{tabular}{|c|c|c|c|c|}
\hline \multirow{2}{*}{$\begin{array}{l}\text { Drying } \\
\text { temperature }\left({ }^{\circ} \mathrm{C}\right)\end{array}$} & \multicolumn{4}{|c|}{ Pigment concn $\left(\mathrm{mg} \cdot \mathrm{g}^{-1} \mathrm{DM}\right)$} \\
\hline & Lutein & $\beta$-carotene & Chl $a^{y}$ & Chl $b^{y}$ \\
\hline & \multicolumn{4}{|c|}{ Spinach high nitrogen $\left(105 \mathrm{mg} \cdot \mathrm{L}^{-1}\right)$} \\
\hline+75 & $0.34 \pm 0.01$ & $0.16 \pm 0.01$ & $0.1 \pm 0.1$ & $0.1 \pm 0.1$ \\
\hline+50 & $0.73 \pm 0.04$ & $0.31 \pm 0.01$ & $1.4 \pm 0.3$ & $0.8 \pm 0.2$ \\
\hline+25 & $1.10 \pm 0.08$ & $0.55 \pm 0.05$ & $10.9 \pm 0.8$ & $4.0 \pm 0.3$ \\
\hline 0 & $1.22 \pm 0.07$ & $0.62 \pm 0.02$ & $11.9 \pm 0.6$ & $4.4 \pm 0.1$ \\
\hline-25 & $1.25 \pm 0.05$ & $0.67 \pm 0.03$ & $12.7 \pm 0.5$ & $4.4 \pm 0.2$ \\
\hline \multicolumn{5}{|l|}{ Contrasts } \\
\hline Linear & $* * *$ & $* * *$ & *** & $* * *$ \\
\hline Quadratic & $* * *$ & $* * *$ & $* * *$ & $* * *$ \\
\hline & \multicolumn{4}{|c|}{ Spinach low nitrogen $\left(13 \mathrm{mg} \cdot \mathrm{L}^{-1}\right)$} \\
\hline+75 & $0.20 \pm 0.03$ & $0.12 \pm 0.01$ & $0.3 \pm 0.2$ & $0.1 \pm 0.1$ \\
\hline+50 & $0.40 \pm 0.04$ & $0.12 \pm 0.01$ & $0.2 \pm 0.1$ & $0.2 \pm 0.1$ \\
\hline+25 & $0.72 \pm 0.04$ & $0.28 \pm 0.02$ & $5.1 \pm 0.3$ & $2.0 \pm 0.1$ \\
\hline 0 & $0.68 \pm 0.03$ & $0.26 \pm 0.02$ & $5.0 \pm 0.3$ & $1.8 \pm 0.1$ \\
\hline-25 & $0.77 \pm 0.06$ & $0.33 \pm 0.03$ & $5.9 \pm 0.4$ & $2.2 \pm 0.2$ \\
\hline \multicolumn{5}{|l|}{ Contrasts } \\
\hline Linear & $* * *$ & $* * *$ & *** & $* * *$ \\
\hline Quadratic & $* * *$ & $* * *$ & $* * *$ & $* * *$ \\
\hline
\end{tabular}

${ }^{\mathrm{z}}$ Mean composition of leaf tissue (pooled six-plant subsample) of three replications $\pm \mathrm{SE}$.

${ }^{\mathrm{y}} \mathrm{Chl} a=$ chlorophyll $a$; Chl $b=$ chlorophyll $b$.

*** Significant at $P \leq 0.001$.

Table 3. Mean pigments concentrations ${ }^{\mathrm{z}}$ expressed on a fresh weight (FM) basis in the leaf tissues of 'Winterbor' kale grown with two nitrogen levels and five drying temperatures.

\begin{tabular}{|c|c|c|c|c|c|}
\hline \multirow{2}{*}{$\begin{array}{l}\text { Drying } \\
\text { temperature }\left({ }^{\circ} \mathrm{C}\right)\end{array}$} & \multirow[b]{2}{*}{$\% \mathrm{DM}$} & \multicolumn{4}{|c|}{ Pigment concn $\left(\mathrm{mg} / 100 \mathrm{~g}^{-1} \mathrm{FM}\right)$} \\
\hline & & Lutein & $\beta$-carotene & Chl $a^{y}$ & Chl $b^{y}$ \\
\hline & & \multicolumn{4}{|c|}{ Kale high nitrogen $\left(105 \mathrm{mg} \cdot \mathrm{L}^{-1}\right)$} \\
\hline+75 & $13.2 \pm 0.5$ & $2.1 \pm 0.3$ & $1.4 \pm 0.1$ & $6.5 \pm 1.8$ & $5.3 \pm 1.2$ \\
\hline+50 & $15.0 \pm 1.4$ & $10.0 \pm 0.2$ & $3.6 \pm 0.2$ & $42.1 \pm 1.0$ & $31.9 \pm 1.4$ \\
\hline+25 & $15.9 \pm 0.4$ & $13.1 \pm 0.4$ & $5.4 \pm 0.2$ & $112.5 \pm 12.4$ & $46.9 \pm 2.3$ \\
\hline 0 & $14.7 \pm 1.8$ & $11.6 \pm 0.8$ & $4.8 \pm 0.4$ & $118.4 \pm 8.2$ & $44.0 \pm 2.4$ \\
\hline-25 & $15.0 \pm 0.5$ & $12.5 \pm 0.7$ & $5.6 \pm 0.3$ & $119.2 \pm 4.6$ & $44.8 \pm 1.8$ \\
\hline \multicolumn{6}{|l|}{ Contrasts } \\
\hline Linear & NS & *** & *** & *** & *** \\
\hline Quadratic & NS & *** & $* * *$ & $* * *$ & $* * *$ \\
\hline & & \multicolumn{4}{|c|}{ Kale low nitrogen $\left(13 \mathrm{mg} \cdot \mathrm{L}^{-1}\right)$} \\
\hline+75 & $21.7 \pm 0.7$ & $0.9 \pm 0.2$ & $0.5 \pm 0.1$ & $1.9 \pm 0.9$ & $2.6 \pm 0.5$ \\
\hline+50 & $22.0 \pm 1.5$ & $5.9 \pm 0.3$ & $1.9 \pm 0.2$ & $10.0 \pm 2.4$ & $11.1 \pm 1.7$ \\
\hline+25 & $22.5 \pm 1.7$ & $9.8 \pm 0.7$ & $3.6 \pm 0.3$ & $62.0 \pm 12.7$ & $28.4 \pm 2.4$ \\
\hline 0 & $21.4 \pm 1.0$ & $9.3 \pm 0.3$ & $2.7 \pm 0.8$ & $75.0 \pm 5.2$ & $33.0 \pm 2.0$ \\
\hline-25 & $21.4 \pm 0.1$ & $9.2 \pm 0.3$ & $3.4 \pm 0.1$ & $80.7 \pm 4.3$ & $32.9 \pm 1.5$ \\
\hline \multicolumn{6}{|l|}{ Contrasts } \\
\hline Linear & NS & *** & *** & $* * *$ & $* * *$ \\
\hline Quadratic & NS & $* * *$ & $* * *$ & $* * *$ & $* * *$ \\
\hline
\end{tabular}

${ }^{2}$ Mean composition of leaf tissue (pooled six-plant subsample) of three replications $\pm \mathrm{SE}$.

${ }^{\mathrm{y}} \mathrm{Chl} a=$ chlorophyll $a$; Chl $b=$ chlorophyll $b$.

Ns, **** Nonsignificant or significant at $P \leq 0.001$, respectively.

$\% \mathrm{DM}=$ percentage of dry matter.

Kale carotenoid and chlorophyll pigment accumulation. The largest lutein accumulation FM in kale was $13.1 \mathrm{mg} / 100 \mathrm{~g}^{-1}$ for the high $\mathrm{N}$ treatment and the $+25{ }^{\circ} \mathrm{C}$ drying temperature (Table 3). Kale leaf tissue lutein concentrations responded to $\mathrm{N}$ treatment $(P \leq 0.001)$, drying temperature $(P \leq 0.001)$, and to the interaction between $\mathrm{N}$ treatment and drying temperature $(P=0.04)$. Kale leaf tissue lutein decreased linearly with increases in drying temperature for both the high $\mathrm{N}$ [lutein $\mathrm{FM}=12.1$ to $0.09(\mathrm{~T}), r^{2}=0.60, P \leq$ 0.001 ] and low $\mathrm{N}$ treatment [lutein $\mathrm{FM}=9.0$ to $\left.0.08(\mathrm{~T}), r^{2}=0.68, P \leq 0.001\right]$.

The largest kale $\beta$-carotene FM was 5.6 $\mathrm{mg} / 100 \mathrm{~g}^{-1}$ with the high $\mathrm{N}$ treatment and the $-25{ }^{\circ} \mathrm{C}$ drying temperature (Table 3 ). Kale leaf tissue $\beta$-carotene concentrations re- in drying temperature for both the high $\mathrm{N}$ $\left[\mathrm{Chl} a \mathrm{FM}=109.9\right.$ to $1.2(\mathrm{~T}), r^{2}=0.80, P \leq$ $0.001]$ and low $\mathrm{N}$ treatments [Chl $a \mathrm{FM}=$ 68.2 to 0.9 (T), $r^{2}=0.83, P \leq 0.001$; Table 3]. Kale leaf tissue Chl $b$ decreased linearly with increases in drying temperature for both the high $\mathrm{N}\left[\mathrm{Chl} b \mathrm{FM}=43.7\right.$ to 0.4 (T), $r^{2}=0.67$, $P \leq 0.001]$ and low N treatments [Chl $b \mathrm{FM}=$ 29.9 to $0.3(\mathrm{~T}), r^{2}=0.84, P \leq 0.001$; Table 3].

The kale maximum lutein DM was 0.84 $\mathrm{mg} \cdot \mathrm{g}^{-1}$ with the high $\mathrm{N}$ treatment and the -25 ${ }^{\circ} \mathrm{C}$ drying temperature (Table 4). Kale leaf tissue lutein concentrations responded to $\mathrm{N}$ treatment $(P \leq 0.001)$, drying temperature $(P \leq 0.001)$, and to the interaction between $\mathrm{N}$ treatment and drying temperature $(P=$ 0.003 ). Kale leaf tissue lutein decreased linearly with increases in drying temperature for both the high $\mathrm{N}$ [lutein $\mathrm{DM}=0.81$ to 0.01 (T), $\left.r^{2}=0.62, P \leq 0.001\right]$ and low $\mathrm{N}$ treatments [lutein $\mathrm{DM}=0.42$ to $0.01(\mathrm{~T}), r^{2}=$ $0.71, P \leq 0.001]$.

The kale maximum $\beta$-carotene DM was $0.37 \mathrm{mg} \cdot \mathrm{g}^{-1}$ with the high $\mathrm{N}$ treatment and the $-25{ }^{\circ} \mathrm{C}$ drying temperature (Table 4). Kale leaf tissue $\beta$-carotene concentrations responded to $\mathrm{N}$ treatment $(P \leq 0.001)$, drying temperature $(P \leq 0.001)$, and to the interaction between $\mathrm{N}$ treatment and drying temperature $(P=0.011)$. Kale leaf tissue $\beta$-carotene decreased linearly with increases in drying temperature for both the high $\mathrm{N}$ $\left[\beta\right.$-carotene $\mathrm{DM}=0.34$ to $0.002(\mathrm{~T}), r^{2}=$ $0.74, P \leq 0.001]$ and low $\mathrm{N}$ treatments $[\beta$ carotene $\mathrm{DM}=0.14+0.001(\mathrm{~T}), r^{2}=0.61$, $P \leq 0.001]$.

Kale leaf tissue DM Chl $a$ and $b$ concentrations responded to $\mathrm{N}$ treatment $(P \leq$ $0.001)$, drying temperature $(P \leq 0.001)$, and to the interaction between $\mathrm{N}$ treatment and drying temperature $(P \leq 0.001)$. Kale leaf tissue Chl $a$ decreased linearly with increases in drying temperature for both the high $\mathrm{N}$ [Chl $a=6.3$ to 0.05 (T), $r^{2}=0.67, P \leq 0.001$ ] and low $\mathrm{N}$ treatments [Chl $a \mathrm{DM}=3.1$ to 0.03 (T), $r^{2}=0.87, P \leq 0.001$; Table 4]. Kale leaf tissue $\mathrm{Chl} b$ decreased linearly with increases in drying temperature for both the high $\mathrm{N}$ $\left[\mathrm{Chl} b \mathrm{DM}=6.3\right.$ to 0.05 (T), $r^{2}=0.67, P \leq$ 0.001 ] and low N treatments [Chl $b=3.1$ to 0.03 (T), $r^{2}=0.87, P \leq 0.001$; Table 4].

\section{Discussion}

sponded to $\mathrm{N}$ treatment $(P \leq 0.001)$, drying temperature $(P \leq 0.001)$, but not to their interaction $(P=0.30)$. Kale leaf tissue $\beta$ carotene decreased linearly with increases in drying temperature for both the high $\mathrm{N}[\beta$ carotene $\mathrm{FM}=5.1$ to 0.04 (T), $r^{2}=0.71, P \leq$ $0.001]$ and low $\mathrm{N}$ treatment $[\beta$-carotene $\mathrm{FM}=$ $\left.3.1+0.03(\mathrm{~T}), r^{2}=0.56, P \leq 0.001\right]$.

Kale leaf tissue FM Chl $a$ concentrations responded to $\mathrm{N}$ treatment $(P \leq 0.001)$, drying temperature $(P \leq 0.001)$, and to the interaction between $\mathrm{N}$ treatment and drying temperature $(P=0.028)$. Kale leaf tissue $\mathrm{Chl} b$ concentrations responded to $\mathrm{N}$ treatment $(P \leq 0.001)$, drying temperature $(P \leq 0.001)$, and to the interaction between $\mathrm{N}$ treatment and drying temperature $(P \leq 0.001)$. Kale leaf tissue Chl $a$ decreased linearly with increases
A consistent drying time of $120 \mathrm{~h}$ was determined for this study based on drying results of the $-50{ }^{\circ} \mathrm{C}$ freeze drying procedure. This method was based on the ASABE Standard (ASABE, 2007) for drying of forages, which requires a $25-\mathrm{g}$ sample be dried at $60{ }^{\circ} \mathrm{C}$ for $72 \mathrm{~h}$. For further chemical analysis of the samples, the ASABE standard does not recommend drying at temperatures above $65^{\circ} \mathrm{C}$. From observations and analytical measurement, a minimum of $100 \mathrm{~h}$ was required for the $-50{ }^{\circ} \mathrm{C}$ freeze-dried samples and was confirmed after another $20 \mathrm{~h}$. To maintain a consistent drying time and reduce possible loss of organic compounds and VOC, the drying time was standardized across the experiment. From observations 
Table 4. Mean pigment concentrations ${ }^{\mathrm{z}}$ expressed on a dry weight (DM) basis in the leaf tissues of 'Winterbor' kale grown with two nitrogen levels and five drying temperatures.

\begin{tabular}{|c|c|c|c|c|}
\hline \multirow{2}{*}{$\begin{array}{l}\text { Drying } \\
\text { temperature }\left({ }^{\circ} \mathrm{C}\right)\end{array}$} & \multicolumn{4}{|c|}{ Pigment Concn (mg.g $\left.{ }^{-1} \mathrm{DM}\right)$} \\
\hline & Lutein & $\beta$-carotene & Chl $a^{y}$ & Chl $b^{y}$ \\
\hline & \multicolumn{4}{|c|}{ Kale high nitrogen $\left(105 \mathrm{mg} \cdot \mathrm{L}^{-1}\right)$} \\
\hline+75 & $0.15 \pm 0.02$ & $0.10 \pm 0.01$ & $0.5 \pm 0.2$ & $0.4 \pm 0.2$ \\
\hline+50 & $0.68 \pm 0.07$ & $0.25 \pm 0.03$ & $2.9 \pm 0.5$ & $2.2 \pm 0.5$ \\
\hline+25 & $0.83 \pm 0.04$ & $0.34 \pm 0.02$ & $8.0 \pm 0.6$ & $3.0 \pm 0.2$ \\
\hline 0 & $0.80 \pm 0.06$ & $0.33 \pm 0.03$ & $8.2 \pm 0.9$ & $3.1 \pm 0.4$ \\
\hline-25 & $0.84 \pm 0.03$ & $0.37 \pm 0.01$ & $8.0 \pm 0.6$ & $3.0 \pm 0.2$ \\
\hline \multicolumn{5}{|l|}{ Contrasts } \\
\hline Linear & $* * *$ & $* * *$ & $* * *$ & $* * *$ \\
\hline Quadratic & *** & $* * *$ & $* * *$ & $* * *$ \\
\hline & \multicolumn{4}{|c|}{ Kale low nitrogen $\left(13 \mathrm{mg} \cdot \mathrm{L}^{-1}\right)$} \\
\hline+75 & $0.04 \pm 0.01$ & $0.02 \pm 0.01$ & $0.1 \pm 0.1$ & $0.1 \pm 0.1$ \\
\hline+50 & $0.28 \pm 0.03$ & $0.09 \pm 0.01$ & $0.5 \pm 0.3$ & $0.5 \pm 0.2$ \\
\hline+25 & $0.44 \pm 0.01$ & $0.15 \pm 0.01$ & $2.7 \pm 0.7$ & $1.3 \pm 0.1$ \\
\hline 0 & $0.44 \pm 0.03$ & $0.12 \pm 0.03$ & $3.5 \pm 0.2$ & $1.6 \pm 0.2$ \\
\hline-25 & $0.43 \pm 0.01$ & $0.16 \pm 0.01$ & $3.8 \pm 0.4$ & $1.5 \pm 0.1$ \\
\hline \multicolumn{5}{|l|}{ Contrasts } \\
\hline Linear & *** & $* * *$ & $* * *$ & $* * *$ \\
\hline Quadratic & $* * *$ & $* * *$ & $* * *$ & $* * *$ \\
\hline
\end{tabular}

${ }^{\mathrm{z}}$ Mean composition of leaf tissue (pooled six-plant subsample) of three replications $\pm \mathrm{SE}$.

${ }^{\mathrm{y}} \mathrm{Chl} a=$ chlorophyll $a$; $\mathrm{Chl} b=$ chlorophyll $b$.

*** Significant at $P \leq 0.001$.

and previous experiments, drying time of the samples in the convection oven $\left(+50{ }^{\circ} \mathrm{C}\right)$ required at least $72 \mathrm{~h}$ to reach moisture equilibrium. From previous personal experience, no differences were noticed when measuring pigment concentrations between freeze-dried samples between 0 and $-50{ }^{\circ} \mathrm{C}$. However, no tests were performed on samples dried in the convection oven until this experiment. The stability of these pigments (lutein, $\beta$-carotene, and chlorophyll) has been reported to be very stable in darkness for 2 weeks below $+45{ }^{\circ} \mathrm{C}$ with measurable changes only occurring after 4 weeks (Daood et al., 2006; Tang and Chen, 2000).

Tissue $\mathrm{N}$ and chlorophyll content has been correlated in a number of studies with lower $\mathrm{N}$ levels resulting in less chlorophyll production. Under limited N, both $\mathrm{Chl} a$ and $b$ pigments are reduced, resulting in potential leaf tissue chlorosis (Taiz and Zeiger, 1998). In the current study, the spinach chlorophyll FM concentrations decreased $17 \%$ and $11 \%$ and the kale decreased $32 \%$ and $26 \%$ for Chl $a$ and $b$, respectively, with decreased N. Lefsrud et al. (2007) reported no significant increases in total chlorophyll concentration for 'Melody' spinach; however, 'Springer' spinach chlorophyll FM increased 23\% when $\mathrm{N}$ rates were increased from 13 to 105 $\mathrm{mg} \cdot \mathrm{L}^{-1}$. Grunwald et al. (1977) reported field tobacco (Nicotiana tabacuin L.) grown with limited $\mathrm{N}$ had a reduction in chlorophyll of $51 \%$ when $\mathrm{N}$ rates were reduced from 336 to $112 \mathrm{~kg} \cdot \mathrm{ha}^{-1}$.

In the current study, the FM lutein and $\beta$-carotene decreased as the $\mathrm{N}$ treatments increased. When measured as a function of $\mathrm{DM}$, lutein concentrations increased as the $\mathrm{N}$ level increased. These results are similar to Lefsrud et al. (2007). Hochmuth et al. (1999) reported a quadratic response in carrot (Daucus carota L.) tissue carotenoids as $\mathrm{N}$ rates increased with maximum carotenoid production occurring at $160 \mathrm{~kg} \cdot \mathrm{ha}^{-1} \mathrm{~N}$.
Lefsrud et al. (2007) reported that 'Melody' spinach tissue lutein, as a function of FM, did not change in response to increasing $\mathrm{N}$ treatment concentrations. However, when lutein was measured on a DM basis for 'Melody' spinach, lutein increased $80 \%$ as the $\mathrm{N}$ level was increased by a factor of eight times. Lefsrud et al. (2007) reported that $\% \mathrm{DM}$ was negatively correlated with $\mathrm{N}$ concentration when growing spinach in nutrient solution culture. In that study, spinach $\% \mathrm{DM}$ varied from $9.6 \%$ at $13 \mathrm{mg} \cdot \mathrm{L}^{-1} \mathrm{~N}$ to $6.9 \%$ at $105 \mathrm{mg} \cdot \mathrm{L}^{-1} \mathrm{~N}$ when the leaf tissue of the plant was oven dried at $+50{ }^{\circ} \mathrm{C}$. In the current study, the \%DM of the spinach samples varied from $6.4 \%$ to $12.7 \%$ for the $\% \mathrm{DM}$ for the kale varied from $13.2 \%$ to $22.5 \%$ for the high and low $\mathrm{N}$ treatments, respectively. It has been reported for many years that plants with elevated $\mathrm{N}$ fertilizer generally possess unusually high water content (Pearsall and Ewing, 1929). This increased water content in addition to increases in the accumulation of other organic compounds (Grunwald et al., 1977; Lefsrud et al., 2007) can affect the loss of organic compounds during drying. The loss of these organic compounds during drying can result in a discrepancy in the calculated pigment concentrations based on either the FM or DM calculations and has been attributed to a dilution effect (Lefsrud et al., 2006, 2007).

Karathanos (1999) and Stegen et al. (1998) reported decreases in \%DM when oven drying temperatures were greater than $+65^{\circ} \mathrm{C}$. Karathanos (1999) suggested that the decrease in \%DM was the result of decomposition of low-molecular-weight sugars during water evaporation. Other researchers working on plants with a high content of essential oils report the loss of VOC as drying temperature increases (Diaz-Maroto et al., 2002a, 2002b, 2004). These results suggest that changes in $\% \mathrm{DM}$ resulting from drying high and low $\mathrm{N}$ treatments, respectively. The temperature and method can be expected in plants with a high content of essential oils, but may also occur with plants without high contents of essential oils.

Lutein, $\beta$-carotene, and chlorophyll levels for both spinach and kale leaf tissues were affected by drying temperature in the current study. Concentrations of all four pigments decreased $\approx 70 \%$ as the drying temperature increased from -25 to $+75{ }^{\circ} \mathrm{C}$. Tai and Chen (2000) reported that oven drying resulted in concentration decreases of $42 \%$ for lutein and $48 \%$ for $\beta$-carotene when compared with freeze drying. Daood et al. (2006) did not report any changes in lutein when red peppers (Capsicum annuum L.) were dried at temperatures less than $50{ }^{\circ} \mathrm{C}$. King et al. (2001) reported that chlorophyll concentrations of vacuum-dried spinach samples (condenser at $-50{ }^{\circ} \mathrm{C}$ ) remained higher than spinach that was dried at $+1{ }^{\circ} \mathrm{C}$. In the current study, the largest spinach pigment FM and DM levels were measured at the $-25{ }^{\circ} \mathrm{C}$ freeze dryer treatment. The largest kale pigment FM and DM levels were split between the $-25{ }^{\circ} \mathrm{C}$ freeze dryer and $+25^{\circ} \mathrm{C}$ vacuum dryer treatments. Comparing data from samples dried between -25 and $+25{ }^{\circ} \mathrm{C}$ resulted in no statistical difference between these drying temperatures. However, a linear decrease was observed in data for drying temperature of $+25,+50$, and $+75^{\circ} \mathrm{C}$. The FM spinach $\beta$ carotene did not follow this trend and decreased as drying temperature increased from -25 to $+25{ }^{\circ} \mathrm{C}$. To limit possible degradation of pigments within kale and spinach tissue, samples should be dried at temperatures below $+25{ }^{\circ} \mathrm{C}$. Hence, the use of vacuum or freeze drying technology is suggested.

\section{Literature Cited}

Alomar, D., R. Fuchslocher, and S. Stockebrand. 1999. Effects of oven- or freeze-drying on chemical composition and NIR spectra of pasture silage. Animal Feed Sci. Tech. 80:309-319.

Ames, B.N., L.S. Gold, and W.C. Willett. 1995. The cause and prevention of cancer. Proc. Natl. Acad. Sci. USA 92:5258-5265.

ASABE. 2007. Moisture measurement-Forages. American Society of Agricultural and Biological Engineers, Standard S358.2. ASABE, St. Joseph, MI.

Cinar, I. 2004. Carotenoid pigment loss of freezedried plant samples under different storage conditions. Lebensmittel-Wissenschaft undTechnologie 37:363-367.

Daood, H.G., J. Kapitany, P. Biacs, and K. Albrecht. 2006. Drying temperature, endogenous antioxidants and capsaicinoids affect carotenoid stability in paprika (red pepper spice). J. Sci. Food Agr. 86:2450-2457.

Davies, B.H. and H.P. Köst. 1988. Chromatographic methods for the separation of carotenoids, p. 1185. In: Köst, H.P., G. Zweig, and J. Sherma (eds.). CRC handbook of chromatography, plant pigments. CRC Press, Boca Raton, FL.

Diaz-Maroto, M.C., E.S. Palomo, L. Castro, M.A.G. Vinas, and M.S. Perez-Coello. 2004. Changes produced in the aroma compounds and structural integrity of basil (Ocimum basilicum L.) during drying. J. Sci. Food Agr. 84:2070-2076. 
Diaz-Maroto, M.C., M.S. Perez-Coello, and M.D. Cabezudo. 2002a. Effect of drying methods on the volatiles in bay leaf (Laurus nobilis L.). J. Agr. Food Chem. 50:4520-4524.

Diaz-Maroto, M.C., M.S. Perez-Coello, and M.D. Cabezudo. 2002b. Effect of different drying methods on the volatile components of parsley (Petroselinum crispum L.). European Food Res. Tech. 215:227-230.

Grunwald, C., J.L. Sims, and S.J. Sheen. 1977. Effects of nitrogen fertilization and stalk position on chlorophyll, carotenoids, and certain lipids of three tobacco genotypes. Can. J. Plant Sci. 57:525-535.

Hoagland, D.R. and D.I. Arnon. 1950. The waterculture method for growing plants without soil. Calif. Agr. Exp. Stat. Circ. 347.

Hochmuth, G.J., J.K. Brecht, and M.J. Bassett. 1999. Nitrogen fertilization to maximize carrot yield and quality on a sandy soil. HortScience 34:641-645.

Holden, J.M., A.L. Eldridge, G.R. Beecher, I.M. Buzzard, S. Bhagwat, C.S. Davis, L.W. Douglass, S. Gebhardt, D. Haytowitz, and S. Schakel. 1999. Carotenoid content of U.S. foods: An update of the database. J. Food Comp. Anal. 12:169-196.

Ingram, L.L., Jr., R. Shmulsky, F.W. Taylor, A.T. Dalton, and M.C. Templeton. 2000. The measurement of volatile organic emissions from drying southern pine lumber in a laboratoryscale kiln. Forest Products J. 50:91-95.

Karathanos, V.T. 1999. Determination of water content of dried fruits by drying kinetics. J. Food Eng. 39:337-344.

King, V.A.E., C.F. Liu, and Y.J. Liu. 2001. Chlorophyll stability in spinach dehydrated by freeze-drying and controlled low-temperature vacuum dehydration. Food Res. Intl. 34:167175.

Kopsell, D.E., D.A. Kopsell, M.G. Lefsrud, J. Curran-Celentano, and L.E. Dukach. 2004. Variation in lutein, beta-carotene, and chlorophyll concentrations among Brassica oleracea cultigens and seasons. HortScience 39:361364.

Landrum, J.T. and R.A. Bone. 2001. Lutein, zeaxanthin, and the macular pigment. Arch. Biochem. Biophys. 385:28-40.

Le Marchand, L., J.H. Hankin, L.N. Kolonel, G.R. Beecher, L.R. Wilkens, and L.P. Zhao. 1993. Intake of specific carotenoids and lung cancer risk. Cancer Epidemiol. Biomarkers Prev. 2: 183-187.

Lefsrud, M.G., D.A. Kopsell, D.E. Kopsell, and J Curran-Celentano. 2005. Air temperature affects biomass and carotenoid pigment accumulation in kale and spinach grown in a controlled environment. HortScience 40:2026-2030.

Lefsrud, M.G., D.A. Kopsell, D.E. Kopsell, and J. Curran-Celentano. 2006. Irradiance affects biomass, elemental concentrations and carotenoid pigments in kale and spinach grown in a controlled environment. Physiol. Plant. 127: 624-631.

Lefsrud, M.G., D.A. Kopsell, D.E. Kopsell, and J. Curran-Celentano. 2007. Nitrogen levels influence biomass, elemental accumulation, and pigment concentrations in spinach. J. Plant Nutr. 30:1-5.

Litvin, S., C.H. Mannheim, and J. Miltz. 1998. Dehydration of carrots by a combination of freeze drying, microwave heating and air or vacuum drying. J. Food Eng. 36:103-111.
Lucier G. and C. Plummer. 2003. Vegetables and melon outlook. Economic Research Service, U.S. Dept. Agr. VGS-297, 20 June 2003.

Miki, W. 1991. Biological functions and activities of animal carotenoids. Pure Appl. Chem. 63:141-146.

Pearsall, W.H. and J. Ewing. 1929. The relation of nitrogen metabolism to plant succulence. Ann. Bot. (Lond.) 43:27-34.

Semba, R.D. and G. Dagnelie. 2003. Are lutein and zeaxanthin conditionally essential nutrients for eye health? Med. Hypotheses 61:465-472.

Steel, R.G.D. and J.H. Torrie. 1980. Principles and procedures of statistics: A biometrical approach. McGraw-Hill, New York, NY.

Stegen, S., F. Queirolo, P. Ostapczuk, A. Groemping, M. Paz, M. Restovic, and C. Carrasco. 1998. Comparison of different methods for the determination of the water content and the dry mass correction factor in various plant samples. Fresenius J. Anal. Chem. 360:601-604.

Tai, C.Y. and B.H. Chen. 2000. Analysis and stability of carotenoids in the flowers of daylily (Hemerocallis disticha) as affected by various treatments. J. Agr. Food Chem. 48:5962-5968.

Taiz, L. and E. Zeiger. 1998. Plant physiology. 2nd Ed. Sinauer Associates, Inc., Sunderland, MA.

Tang, Y.C. and B.H. Chen. 2000. Pigment change of freeze-dried carotenoid powder during storage. Food Chem. 69:11-17.

Tracewell, C.A., J.S. Vrettos, J.A. Bautista, H.A. Frank, and G.W. Brudvig. 2001. Carotenoid photooxidation in photosystem II. Arch. Biochem. Biophys. 385:61-69.

U.S. Dept. Agr. 2002. National nutrient database for standard reference, release 15. NDB No: 11457. U.S. Dept. Agr., Washington, DC. 